\title{
Investigating the effect of premenstrual syndrome in high school students doing regular sports
}

\author{
Mine Akkus ${ }^{1}$ \\ Kemal Tamer ${ }^{2}$ \\ Ebru Cetin ${ }^{3}$
}

\begin{abstract}
Present study was aimed to investigate the effect of regular exercise on premenstrual syndrome (PMS) in high school students. A total of 252 high school students who involved in regularly $(\mathrm{n}=$ $117)$ and sedentary students $(\mathrm{n}=135)$ participated in the study. The personal information form was used to determine the age group and sports status of the participants and the Premenstrual Syndrome Scale (PMSS) developed by Gençdoğan (2006) consisting of 44 questions was used to determine the premenstrual syndrome levels. Mann Whitney $U$ and Kruskal Wallis $H$ tests were used in SPSS 22.0 program for statistical analysis of data obtained. At the end of the study, the level of PMS was found to be significantly higher in the sedentary students compared to the students who participated regularly in sports $(p<0.05)$. When handled according to age group variable, it was found out the students who regularly in sports did not show any statistically significant difference in depressive affection, anxiety, fatigue, nervousness, depressive thoughts, pain, bloating, appetite changes and PMS total syndrome levels ( $>>0.05)$. In the sedentary students, depressive affection and anxiety subscales were found to be statistically significant in favor of students in the age group of 17 years $(p<0.05)$. As a result, it is possible to say that the participation in sports in high school students has a positive contribution to PMS, while the age factor holds a significant effect on the symptoms on PMS.
\end{abstract}

Keywords: High school students; sports; menstruation; menstrual cycle; premenstrual syndrome.

\section{Introduction}

On the development of women's over function and as a result of these developments, the beginning of reproductive ability is called "menstruation". This period is specific to female and the reproductive function does not take place in this period (Çakmakçı et al., 2005). While the hormonal structures of males usually follow a steady course, constant changes occur in the hormonal structures of females (Karp and Smith, 2012). Menstrual cycles are at the beginning of the process in which hormonal changes take place. While menstrual cycles show hormonal differences according to gender, the effects of sportsive performance are mostly debated (Ön, 2012).

\footnotetext{
${ }^{1}$ Ph.D Student, Gazi University, Educational Science Institute, Physical Education and Sports Teaching Department, Ankara Turkey, mine akkus@,hotmail.com

2 Prof. Dr., Gazi University, School of Physical Education and Sports, Ankara, Turkey, ktamer@gazi.edu.tr

${ }^{3}$ Assoc. Prof., Gazi University, School of Physical Education and Sports, Ankara, Turkey, ecetin@gazi.edu.tr
} 
Akkus, M. Tamer, K., \& Cetin, E. (2017).Investigating the effect of premenstrual syndrome in high school students doing regular sports. Journal of Human Sciences, 14(4), 3379-3388. doi:10.14687/jhs.v14i4.4517

In women, there are some problems in menstrual period leading to premenstrual syndrome (PMS) and PMS prevalence of is 5-8\% (Yonkers et al., 2008: 1200). PMS is a problem characterized with the emotional and physical symptoms usually observed in the luteal phase of the menstrual cycle in women of young and middle age group (Dickerson et al., 2003: 1743). PMS begins in the luteal phase and ends with the onset of PMS menstruation. Although PMS, which affects women's quality of life negatively whose aetiology is not known precisely, it is estimated that it affects millions of women worldwide (Öztürk and Tanriverdi, 2010). For this reason, in order to increase the quality of life of women, it is emphasized that research on PMS should be given importance (Kebapcilar et al., 2012).

It is known that exercise has an important function in the maintanance of health and prevention of diseases. For this reason, participation in exercise seems to have an important place of human life whichever age (Çakmakçı et al., 2005). The research findings addressing the effects of participation of exercise on health also support the idea that exercise is very effective in the maintanence and development of health from different perspectives. When the studies done on this subject are examined, it was observed that the exercise has beneficial results in terms of psychological (Sahin, 2015; Keskin, 2014) and physical aspects (Janssen et al., 2005; Brown et al., 2003).

In recent years, many changes have occurred in the social structures of societies, in which societies have begun to exhibit positive attitudes towards the sports. In this background, women's attitudes towards sports have also improved in the positive way (Roupas and Georgopoulos, 2011, Hekim, 2016). In parallel with the increasing levels of women's attitudes towards sports activities, the number of studies related to the effects of sports on morphological and physiological structure of women has increased (Karacan and Çolakoğlu, 2003). The changes in the hormonal structures of women during the menstruation process contributed to direct the studies towards examining the changes in the sportive performances of women. As a result of the literature review, it was observed that the study practised in this area generally focused on the effects of the menstruation process on the sportive performance, as well as the menstrual disorders observed in female athletes. On the other hand, it has been observed that the researches on the effects of regular exercise on the premenstrual syndrome are limited. In this study, it was aimed to investigate the effect of regular exercise on premenstrual syndrome in high school students.

\section{Material and Method}

\section{Research Model}

In this research, survey research method from observation-based (empirical) research models which are frequently used in sports sciences was used. Observational researches are composed of the researches conducted by using surveys and scales in order to answer the questions desired, to develop hypotheses to test whether the questions to be answered are correct or not. In observational studies, statistical analysis of data obtained is included to test the hypotheses. Survey type studies categorized in observational studies are known as descriptive research methods used to determine the characteristics (age, marital status, sex, etc.) of research subjects of large sample groups (Can, 2014: 8).

\section{Research Group}

A total of 252 high school students voluntarily participated in the survey, including 117 high school students doing sports regularly and 135 sedentary students. In this content, Etimesgut Anatolian High School students who has habit of sedentary lifestyle were chosen randomly and participants involved regularly in sports were chosen randomly from Ankara TVF (Turkish Volleyball Federation) Sports High School.

\section{Data Collection}

For the determination of the data about the age and sports status of high school students participating in the research, a personal information form consisting of two questions was utilized. Developed by Gençdoğan (2006) Premenstrual Syndrome Scale (PMS), composed of 44 questions 
Akkus, M. Tamer, K., \& Cetin, E. (2017).Investigating the effect of premenstrual syndrome in high school students doing regular sports. Journal of Human Sciences, 14(4), 3379-3388. doi:10.14687/jhs.v14i4.4517

was used to determine premenstrual syndrome levels of the participants. "No" option is evaluated as 1 point, "very few" option is 2 points, "occasionally" option is 3 points, "often" option is 4 points, "permanent" option is 5 points. Depressive affection (1., 2., 3., 4., 5., 6. and 7. items), anxiety (8., 9., 10., 11., 13., 15. and 16. items), fatigue (12., 14., 17., 18., 25. and 37. items), nervousness (19., 20., 21., 22. and 23. items), depressive thoughts (24., 26., 27.,28., 29.,30. and 44. items), pain (31., 32. and 33. item), appetite changes (38., 39., and 40. items), bloating (41., 42., and 43. items) composed of 9 subscales and PMS total scores of the subscales obtained from all the subscales. The lowest score that can be taken from the scale is 44 , the highest score is 220 . The higher the score, the greater the prevalence of premenstrual syndrome symptoms (Erbil et al., 2011: 431).

\section{Statistical Analysis}

SPSS 22.0 program was used in the analysis of the obtained data. It was examined whether the participants had a normal distribution before the scores obtained from the subscales of the participants were analyzed. According to the one-sample Kolmogorov-Smirnov test results, it was determined that the data did not show a normal distribution. For this reason, non-parametric analysis methods were used when the data were analyzed according to sports status and age groups. The Mann Whitney U test was used for the comparison of the scale scores according to the sports status, whereas the Kruskal Wallis $\mathrm{H}$ test was used for the comparison of scale scores to the age groups. Mann Whitney U test was used as a post hoc test to determine the difference between the age groups when significant differences were found. Cronbach's Alpha values for the scale subscales ranged from 742 to 946.

\section{Findings}

Table 1. Frequency and Percentage Distributions of Participants' Sports Status and Age Groups

\begin{tabular}{lccc}
\hline Variables & Sub-variables & $\mathbf{f}$ & $\mathbf{\%}$ \\
\hline \multirow{2}{*}{ Sports Status } & Sportss Group & 117 & 46,4 \\
\cline { 2 - 4 } & Sedentary Group & 135 & 53,6 \\
\cline { 2 - 4 } Age Groups & 14 age & 29 & 11,5 \\
\cline { 2 - 4 } & 15 age & 63 & 25,0 \\
\cline { 2 - 4 } & 16 age & 126 & 50,0 \\
\hline
\end{tabular}

$46,4 \%$ of the participants have the habit of participating in sports regularly, $53,6 \%$ are sedentary participants. $11.5 \%$ of the survey participants are in the age group of $14,25 \%$ are in the age group of $15,50 \%$ are in the age group of 16 and $13.5 \%$ in the age group of 17 .

Table 2. Descriptive Statistics of Participants' PMS Scale Scores

\begin{tabular}{lccccc}
\hline Sub-scales & $\mathbf{n}$ & The Lowest & The Highest & X & Sd \\
\hline Depressive affection & 252 & 7 & 35 & 22,45 & 5,458 \\
\hline Anxiety & 252 & 7 & 33 & 20,98 & 5,611 \\
\hline Fatigue & 252 & 6 & 30 & 20,25 & 4,851 \\
\hline Nervousness & 252 & 5 & 25 & 16,68 & 4,236 \\
\hline Depressive Thoughts & 252 & 7 & 34 & 22,50 & 6,282 \\
\hline Pain & 252 & 3 & 15 & 10,18 & 3,349 \\
\hline Appetite Changes & 252 & 3 & 15 & 10,81 & 2,940 \\
\hline Bloating & 252 & 3 & 15 & 10,20 & 3,175 \\
\hline PMS Total & 252 & 47 & 200 & 144,73 & 29,500 \\
\hline
\end{tabular}

When the table 2 was examined, it was observed that the participants had over moderate scores of depression, fatigue, nervousness, depressive thoughts, pain, appetite changes, bloating and PMS total scores; anxiety scores were moderate. 
Akkus, M. Tamer, K., \& Cetin, E. (2017).Investigating the effect of premenstrual syndrome in high school students doing regular sports. Journal of Human Sciences, 14(4), 3379-3388. doi:10.14687/jhs.v14i4.4517

Table 3. Descriptive Statistics on Comparing Participants' PMS Scale Scores According to Regular Sports Status

\begin{tabular}{lllll}
\hline Sub-scales & Sports Status & $\mathbf{n}$ & $\mathbf{X}$ & $\mathbf{S d}$ \\
\hline \multirow{2}{*}{ Depressive affection } & Sports Group & 117 & 20,52 & 6,497 \\
\cline { 2 - 5 } & Sedentary Group & 135 & 24,12 & 3,635 \\
\hline \multirow{2}{*}{ Anxiety } & Sports Group & 117 & 17,30 & 5,289 \\
\cline { 2 - 5 } & Sedentary Group & 135 & 24,17 & 3,561 \\
\hline \multirow{2}{*}{ Fatigue } & Sports Group & 117 & 17,35 & 2,478 \\
\cline { 2 - 5 } & Sedentary Group & 135 & 22,77 & 5,437 \\
\hline \multirow{2}{*}{ Nervousness } & Sports Group & 117 & 15,24 & 2,152 \\
\cline { 2 - 5 } & Sedentary Group & 135 & 17,93 & 5,582 \\
\hline \multirow{2}{*}{ Depressive } & Sports Group & 117 & 17,77 & 3,235 \\
\hline \multirow{2}{*}{ Pain } & Sedentary Group & 135 & 26,60 & 2,160 \\
\hline \multirow{2}{*}{ Appetite Changes } & Sports Group & 117 & 8,07 & 3,025 \\
\cline { 2 - 5 } & Sedentary Group & 135 & 12,01 & 1,847 \\
\hline \multirow{2}{*}{ Bloating } & Sports Group & 117 & 9,09 & 2,928 \\
\cline { 2 - 5 } & Sedentary Group & 135 & 12,31 & 1,971 \\
\hline \multirow{2}{*}{ PMS Total } & Sports Group & 117 & 12,04 & 12,107 \\
\cline { 2 - 5 } & Sedentary Group & 135 & 123,39 & 1626 \\
\hline
\end{tabular}

When the table 3 was examined, the level of syndrome in all subscales of sedentary participants and the total of PMS was higher than that of participants involved in sports.

Table 4. Mann Whitney U 'Test Results for Participants' Comparison of PMS Scale Scores According to Regular Sports Status

\begin{tabular}{|c|c|c|c|c|c|}
\hline Sub-scales & Sports Status & Range ave. & Range Total. & $\mathbf{U}$ & $\mathbf{P}$ \\
\hline \multirow{2}{*}{$\begin{array}{l}\text { Depressive } \\
\text { affection }\end{array}$} & Sports Group & 99,55 & 11647,0 & \multirow{2}{*}{4744,0} & \multirow{2}{*}{000} \\
\hline & Sedentary Group & 149,86 & 20231,0 & & \\
\hline \multirow{2}{*}{ Anxiety } & Sports Group & 78,03 & 9130,0 & \multirow{2}{*}{2227,0} & \multirow{2}{*}{000} \\
\hline & Sedentary Group & 168,50 & 22748,0 & & \\
\hline \multirow{2}{*}{ Fatigue } & Sports Group & 83,46 & 9764,5 & \multirow{2}{*}{2861,5} & \multirow{2}{*}{,000 } \\
\hline & Sedentary Group & 163,80 & 22113,5 & & \\
\hline \multirow{2}{*}{ Nervousness } & Sports Group & 100,23 & 11726,5 & \multirow{2}{*}{4823,5} & \multirow{2}{*}{, 000} \\
\hline & Sedentary Group & 149,27 & 20151,5 & & \\
\hline \multirow{2}{*}{$\begin{array}{l}\text { Depressive } \\
\text { Thoughts }\end{array}$} & Sports Group & 71,82 & 8402,5 & \multirow{2}{*}{1499,5} & \multirow{2}{*}{,000 } \\
\hline & Sedentary Group & 173,89 & 23475,5 & & \\
\hline \multirow{2}{*}{ Pain } & Sports Group & 81,30 & 9512,0 & \multirow{2}{*}{2609,0} & \multirow{2}{*}{000} \\
\hline & Sedentary Group & 165,67 & 22366,0 & & \\
\hline Appetite & Sports Group & 83,66 & 9788,0 & \multirow{2}{*}{2885,0} & \multirow{2}{*}{000} \\
\hline Changes & Sedentary Group & 163,63 & 22090,0 & & \\
\hline \multirow{2}{*}{ Bloating } & Sports Group & 77,12 & 9023,0 & \multirow{2}{*}{2120,0} & \multirow{2}{*}{,000 } \\
\hline & Sedentary Group & 169,30 & 22855,0 & & \\
\hline \multirow{2}{*}{ PMS Total } & Sports Group & 74,44 & 8709,0 & \multirow{2}{*}{1806,0} & \multirow{2}{*}{,000 } \\
\hline & Sedentary Group & 171,62 & 23169,0 & & \\
\hline
\end{tabular}

When the table 4 was examined, there was a statistically significant difference between the levels of syndromes in all subscales of participants involved in sports regularly and sedentary participants and total of PMS ( $\mathrm{p}<0.05)$. 
Akkus, M. Tamer, K., \& Cetin, E. (2017).Investigating the effect of premenstrual syndrome in high school students doing regular sports. Journal of Human Sciences, 14(4), 3379-3388. doi:10.14687/jhs.v14i4.4517

Table 5. Descriptive statistics on the comparison of PMS scale scores according to age groups of participants involved in sports regularly

\begin{tabular}{|c|c|c|c|c|}
\hline Sub-scales & Age Groups & $\mathbf{P}$ & $\mathbf{X}$ & Sd \\
\hline \multirow{4}{*}{ Depressive affection } & 14 age & 28 & 21,21 & 6,161 \\
\hline & 15 age & 24 & 19,46 & 7,425 \\
\hline & 16 age & 40 & 20,65 & 6,997 \\
\hline & 17 age & 25 & 20,56 & 5,221 \\
\hline \multirow{4}{*}{ Anxiety } & 14 age & 28 & 19,18 & 5,375 \\
\hline & 15 age & 24 & 16,58 & 5,679 \\
\hline & 16 age & 40 & 17,35 & 5,475 \\
\hline & 17 age & 25 & 15,80 & 4,010 \\
\hline \multirow{4}{*}{ Fatigue } & 14 age & 28 & 17,93 & 5,228 \\
\hline & 15 age & 24 & 16,83 & 5,799 \\
\hline & 16 age & 40 & 18,08 & 5,976 \\
\hline & 17 age & 25 & 16,04 & 4,550 \\
\hline \multirow{4}{*}{ Nervousness } & 14 age & 28 & 15,82 & 5,963 \\
\hline & 15 age & 24 & 13,92 & 5,948 \\
\hline & 16 age & 40 & 16,18 & 4,888 \\
\hline & 17 age & 25 & 14,36 & 5,073 \\
\hline \multirow{4}{*}{$\begin{array}{l}\text { Depressive } \\
\text { Thoughts }\end{array}$} & 14 age & 28 & 19,11 & 5,633 \\
\hline & 15 age & 24 & 17,08 & 6,227 \\
\hline & 16 age & 40 & 18,20 & 5,506 \\
\hline & 17 age & 25 & 16,24 & 4,816 \\
\hline \multirow{4}{*}{ Pain } & 14 age & 28 & 8,43 & 3,214 \\
\hline & 15 age & 24 & 7,92 & 3,189 \\
\hline & 16 age & 40 & 8,15 & 3,247 \\
\hline & 17 age & 25 & 7,68 & 3,449 \\
\hline \multirow{4}{*}{ Appetite Changes } & 14 age & 28 & 9,54 & 2,617 \\
\hline & 15 age & 24 & 10,25 & 3,096 \\
\hline & 16 age & 40 & 8,58 & 3,396 \\
\hline & 17 age & 25 & 8,28 & 2,424 \\
\hline \multirow{4}{*}{ Bloating } & 14 age & 28 & 7,82 & 2,611 \\
\hline & 15 age & 24 & 7,75 & 3,529 \\
\hline & 16 age & 40 & 7,55 & 2,745 \\
\hline & 17 age & 25 & 9,36 & 2,691 \\
\hline \multirow{4}{*}{ PMS Total } & 14 age & 28 & 128,54 & 29,288 \\
\hline & 15 age & 24 & 120,13 & 33,958 \\
\hline & 16 age & 40 & 124,55 & 28,724 \\
\hline & 17 age & 25 & 118,92 & 24,886 \\
\hline
\end{tabular}

When the table 5 was examined, participants in the 14-year-old age group were observed with the highest levels of depressive affection, anxiety, depressive thoughts, pain, and PMS total syndrome. The participants with the highest fatigue and nervousness syndrome were participants in the 16-year-old age, the participants with the highest syndrome in the appetite change syndrome in the 15-year-old group, and the participants in the 17-year-old age with the highest syndrome in the bloating syndrome. 
Akkus, M. Tamer, K., \& Cetin, E. (2017).Investigating the effect of premenstrual syndrome in high school students doing regular sports. Journal of Human Sciences, 14(4), 3379-3388. doi:10.14687/jhs.v14i4.4517

Table 6. Mann Whitney U Test Results Regarding Comparison of PMS Scale Scores According to Age Groups of Regular Sports Participants

\begin{tabular}{|c|c|c|c|c|}
\hline Sub-scales & Age Groups & Range Ave. & $\mathrm{x}^{2}$ & $\mathbf{P}$ \\
\hline \multirow{4}{*}{ Depressive affection } & 14 age & 61,59 & \multirow{4}{*}{1,122} & \multirow{4}{*}{, 772} \\
\hline & 15 age & 52,85 & & \\
\hline & 16 age & 61,16 & & \\
\hline & 17 age & 58,54 & & \\
\hline \multirow{4}{*}{ Anxiety } & 14 age & 69,00 & \multirow{4}{*}{4,830} & \multirow{4}{*}{,185 } \\
\hline & 15 age & 55,48 & & \\
\hline & 16 age & 60,20 & & \\
\hline & 17 age & 49,26 & & \\
\hline \multirow{4}{*}{ Fatigue } & 14 age & 60,30 & \multirow{4}{*}{1,462} & \multirow{4}{*}{ 691 } \\
\hline & 15 age & 55,60 & & \\
\hline & 16 age & 63,25 & & \\
\hline & 17 age & 54,00 & & \\
\hline \multirow{4}{*}{ Nervousness } & 14 age & 61,14 & \multirow{4}{*}{3,437} & \multirow{4}{*}{,329 } \\
\hline & 15 age & 51,00 & & \\
\hline & 16 age & 65,41 & & \\
\hline & 17 age & 54,02 & & \\
\hline \multirow{4}{*}{ Depressive Thoughts } & 14 age & 64,30 & \multirow{4}{*}{2,958} & \multirow{4}{*}{,398 } \\
\hline & 15 age & 55,88 & & \\
\hline & 16 age & 62,55 & & \\
\hline & 17 age & 50,38 & & \\
\hline \multirow{4}{*}{ Pain } & 14 age & 62,14 & \multirow{4}{*}{1,128} & \multirow{4}{*}{, 770} \\
\hline & 15 age & 58,06 & & \\
\hline & 16 age & 60,96 & & \\
\hline & 17 age & 53,24 & & \\
\hline \multirow{4}{*}{ Appetite Changes } & 14 age & 63,95 & \multirow{4}{*}{9,183} & \multirow{4}{*}{, 027} \\
\hline & 15 age & 74,35 & & \\
\hline & 16 age & 52,40 & & \\
\hline & 17 age & 49,28 & & \\
\hline \multirow{4}{*}{ Bloating } & 14 age & 56,23 & \multirow{4}{*}{6,035} & \multirow{4}{*}{,110 } \\
\hline & 15 age & 55,25 & & \\
\hline & 16 age & 54,06 & & \\
\hline & 17 age & 73,60 & & \\
\hline \multirow{4}{*}{ PMS Total } & 14 age & 60,79 & \multirow{4}{*}{,516 } & \multirow{4}{*}{,915 } \\
\hline & 15 age & 57,17 & & \\
\hline & 16 age & 60,93 & & \\
\hline & 17 age & 55,68 & & \\
\hline
\end{tabular}

When the table 6 was examined, it was observed that the participants involved in sports did not differ statistically in the subscales of depressive affection, anxiety, fatigue, nervousness, depressive thoughts, pain, bloating and PMS total syndrome levels with respect to age groups ( $\mathrm{p}>$ $0,05)$, however the appaetite changes showed statistically significant difference $(p<0.05)$. According to the results of post host test to determine which groups of significant difference in appetite change syndrome, the difference stems from the fact that the syndrome level of the participants in the 15 years age group is higher than the syndrome level of 16 years and 17 years age group participants. 
Akkus, M. Tamer, K., \& Cetin, E. (2017).Investigating the effect of premenstrual syndrome in high school students doing regular sports. Journal of Human Sciences, 14(4), 3379-3388. doi:10.14687/jhs.v14i4.4517

Table 7. Descriptive Statistics on the Comparison of PMS Scale Scores According to Age Groups of Sedentary Participants

\begin{tabular}{|c|c|c|c|c|}
\hline Sub-scales & Age Groups & $\mathbf{P}$ & $\mathbf{X}$ & Sd \\
\hline \multirow{3}{*}{$\begin{array}{l}\text { Depressive } \\
\text { Affection }\end{array}$} & 15 age & 40 & 24,25 & 4,337 \\
\hline & 16 age & 86 & 23,73 & 3,255 \\
\hline & 17 age & 9 & 27,22 & 2,108 \\
\hline \multirow{3}{*}{ Anxiety } & 15 age & 40 & 24,05 & 4,557 \\
\hline & 16 age & 86 & 23,95 & 2,982 \\
\hline & 17 age & 9 & 26,78 & 2,906 \\
\hline \multirow{3}{*}{ Fatigue } & 15 age & 40 & 22,48 & 2,160 \\
\hline & 16 age & 86 & 22,85 & 2,072 \\
\hline & 17 age & 9 & 23,33 & 2,000 \\
\hline \multirow{3}{*}{ Nervousness } & 15 age & 40 & 17,93 & 1,927 \\
\hline & 16 age & 86 & 17,78 & 2,111 \\
\hline & 17 age & 9 & 19,44 & 3,046 \\
\hline \multirow{3}{*}{$\begin{array}{l}\text { Depressive } \\
\text { Thoughts }\end{array}$} & 15 age & 40 & 26,45 & 3,250 \\
\hline & 16 age & 86 & 26,52 & 3,328 \\
\hline & 17 age & 9 & 28,00 & 1,936 \\
\hline \multirow{3}{*}{ Pain } & 15 age & 40 & 12,18 & 2,510 \\
\hline & 16 age & 86 & 11,91 & 2,056 \\
\hline & 17 age & 9 & 12,22 & 1,481 \\
\hline \multirow{3}{*}{ Appetite Changes } & 15 age & 40 & 12,60 & 1,780 \\
\hline & 16 age & 86 & 12,20 & 1,859 \\
\hline & 17 age & 9 & 12,11 & 2,088 \\
\hline \multirow{3}{*}{ Bloating } & 15 age & 40 & 12,55 & 2,183 \\
\hline & 16 age & 86 & 11,81 & 1,876 \\
\hline & 17 age & 9 & 12,33 & 1,581 \\
\hline \multirow{3}{*}{ PMS Total } & 15 age & 40 & 163,55 & 14,735 \\
\hline & 16 age & 86 & 162,12 & 11,262 \\
\hline & 17 age & 9 & 172,44 & 8,428 \\
\hline
\end{tabular}

When the table 7 was examined, while sedentary participants in the age group of 17 years the highest level of syndrome in depressive affection, anxiety, fatigue, nervousness, depressive thoughts, pain and PMS total syndrome, participants in the age group of 15 years have the highest syndrome level in appetite changes and bloating syndromes.

Table 8. Mann Whitney U Test Results In Comparison of PMS Scale Scores According to Age Groups of Sedentary Participants

\begin{tabular}{|c|c|c|c|c|}
\hline Sub-scales & Age Groups & Range Ave. & $x^{2}$ & $\mathbf{P}$ \\
\hline \multirow{3}{*}{ Depressive Affection } & 15 age & 69,90 & \multirow{3}{*}{9,501} & \multirow{3}{*}{009} \\
\hline & 16 age & 63,24 & & \\
\hline & 17 age & 105,00 & & \\
\hline \multirow{3}{*}{ Anxiety } & 15 age & 70,74 & \multirow{3}{*}{7,023} & \multirow{3}{*}{,030 } \\
\hline & 16 age & 63,50 & & \\
\hline & 17 age & 98,83 & & \\
\hline \multirow{3}{*}{ Fatigue } & 15 age & 62,59 & \multirow{3}{*}{1,343} & \multirow{3}{*}{, 511} \\
\hline & 16 age & 69,67 & & \\
\hline & 17 age & 76,11 & & \\
\hline \multirow{3}{*}{ Nervousness } & 15 age & 67,69 & \multirow{3}{*}{2,286} & \multirow{3}{*}{,319 } \\
\hline & 16 age & 66,19 & & \\
\hline & 17 age & 86,67 & & \\
\hline \multirow{3}{*}{ Depressive Thoughts } & 15 age & 66,21 & \multirow{3}{*}{2,247} & \multirow{3}{*}{,325 } \\
\hline & 16 age & 66,87 & & \\
\hline & 17 age & 86,72 & & \\
\hline \multirow{3}{*}{ Pain } & 15 age & 72,40 & \multirow{3}{*}{, 791} & \multirow{3}{*}{,673 } \\
\hline & 16 age & 65,88 & & \\
\hline & 17 age & 68,72 & & \\
\hline
\end{tabular}


Akkus, M. Tamer, K., \& Cetin, E. (2017).Investigating the effect of premenstrual syndrome in high school students doing regular sports. Journal of Human Sciences, 14(4), 3379-3388. doi:10.14687/jhs.v14i4.4517

\begin{tabular}{|c|c|c|c|c|}
\hline \multirow{3}{*}{ Appetite Changes } & 15 age & 73,59 & \multirow{3}{*}{1,209} & \multirow{3}{*}{,546 } \\
\hline & 16 age & 65,74 & & \\
\hline & 17 age & 64,72 & & \\
\hline \multirow{3}{*}{ Bloating } & 15 age & 78,78 & \multirow{3}{*}{4,900} & \multirow{3}{*}{,086 } \\
\hline & 16 age & 62,57 & & \\
\hline & 17 age & 72,00 & & \\
\hline \multirow{3}{*}{ PMS Total } & 15 age & 70,05 & \multirow{3}{*}{7,914} & \multirow{3}{*}{,019 } \\
\hline & 16 age & 63,52 & & \\
\hline & 17 age & 101,67 & & \\
\hline
\end{tabular}

When the table 8 was examined, it was observed that fatigue, nervousness, depressive thoughts, pain, appetite changes, bloating and PMS total syndrome, levels of sedentary participants did not differ statistically according to age groups ( $>0,05)$, however depressive affection, anxiety and PMS total syndrome levels $(\mathrm{P}<0,05)$ showed significant difference according to age groups. According to the post hoc test results performed to determine the difference between groups with significantly different subscales, the difference in the anxiety and PMS total syndrome was due to the fact that the syndrome level of the participants in the 17 years age group was higher than the syndrome level of the 16 years age group and the difference in the depressive affection syndrome, the level of the syndrome stems from the fact that participants of 17 years was higher than the syndrome level of both 15 and 16 years group.

\section{Discussion and Conclusion}

When compared to sedentary high school students, it was found that the students involved in sports regularly had lower scores on the PMS subscale, and similarly the total PMS score was lower in favor of students with regular sports participation. These findings reveal that the frequency of PMS was higher in sedentary high school students than students with regular sports participation.

According to Serena et al. (2001), regular exercise inhibits the reduction of endorphin release in the luteal phase of the menstrual cycle, as well as contributing to the reduction of affection symptoms. In this respect, regular exercise is considered as an element contributing to the reduction of PMS symptoms (Quoted by: Öztürk and Tanriverdi, 2010: 59). For this reason, it is recommended to exercise regularly for women who show signs of PMS (Kebapçlar et al., 2012: 113, Süer, 2008: 77).

In the study conducted by Bayram (2007: 107) it was aimed to investigate the frequency of PMS in athlete women and sedentary women. A total of 189 women, 93 athletes and 96 sedentary participants were included in the study between the age range of 17-36. At the end of the study, sedentary women were found to have more severe affection disturbances due to PMS compared to athletes women. A similar study conducted by Lustyk et al. (2004: 35) aimed to examine the relationship between the frequency of exercise and the symptoms of PMS in women aged 18-33 years. It was found that the frequency of exercising in women with age range of 18-33 was a significant determinant on PMS. According to the findings, the frequency of PMS-related stress was higher in women who exercised frequently compared to women who exercise occasionally. In another study conducted by Sokullu and Aksu (2015: 54), it was aimed to investigate the lifestyle behaviors of women who applied to the hospital with PMS complaints and at the end of the research, it was determined that women having PMS have very low levels of participation in exercising. When the research findings in the literature are evaluated, it is observed that the results obtained in this study were in parallel with the literature.

In this study, PMS levels of high school students involved in sports regularly were examined according to the age group variable, it was interpreted that the students in the 15 years age group had a higher mean score in the subscale of appetite changes compared to the students in the 16 and 17 age groups. In the students with regular sports participation, the findings of other PMS subscales and total PMS score did not show any significant difference according to the age 
Akkus, M. Tamer, K., \& Cetin, E. (2017).Investigating the effect of premenstrual syndrome in high school students doing regular sports. Journal of Human Sciences, 14(4), 3379-3388. doi:10.14687/jhs.v14i4.4517

group variable. According to these findings, it can be said that the age variable is not a significant determinant on PMS in the students with regular sports participation. At the basis of this outcome, it can be considered that regular exercise reduces PMS symptoms. Research findings in the literature also support the view that PMS symptoms decreases as the frequency of exercising increases in women (Demir et al., 2006: 262).

When the PMS levels of sedentary high school students in the study were examined according to the age group variable, it was concluded that the depressive affection and anxiety subscales and the total PMS score average were higher in favor of the students in the 17 years age group. According to these findings, it can be said that affection disturbances related to PMS are more frequent in sedentary high school students in the older age group when compared to the students in younger age group. On the basis of this outcome, it can be considered that the high school students' hormonal changes in their bodies during the menstruation period vary according to age groups. It is emphasized that sex hormones lies on the basis of the emotional and behavioral symptoms observed in the PMS process in the study by Yonkers et al. (2008: 1203).

In sedentary high school students in age group of 17, besides PMS total score, it can be considered that the background of high scores in depressive affection and anxiety subscales PMS prepares the basis for affection disorders. A similar study on athletes and sedentary women, Bayram (2007: 104) also found that PMS changes are more severe due to the frequency of symptoms of depression.

In conclusion, while exercise has positive effects on general health, it is also known that it has some positive effects on hormonal structure. At the beginning of the process of changes in the hormonal structures of women which is the period of menstruation, and the hormonal changes that take place during this period sometimes pave the way for the symptoms of PMS in women. Exercising has a protective role in the minimization of the symptoms of PMS. In this study, it was found that the PMS level was higher in sedentary students when compared to the high school students involved in sports regularly. The result obtained in the research was found to be in parallel with the literature. Findings obtained in the research and the related literature suggests that participation in exercise would be beneficial to reduce the incidence of PMS in women.

\section{References}

Bayram O.G. (2007). Sporcuların Premenstrual Sendrom Yönünden Sedanter Bayanlarla Karşılaştırılması. Bakırkëy Tip Dergisi. 3(3): 104-110.

Brown, D.W., Balluz, L.S., Heath, G.W., Moriarty, D.G., Ford, E.S., Giles, W.H., Mokdad, A.H. (2003). Associations Between Recommended Levels of Physical Activity and HealthRelated Quality of Life Findings From The 2001 Behavioral Risk Factor Surveillance System (BRFSS) Survey. Preventive Medicine. 37: 520-528.

Can, A. (2014). SPSS İle Bilimsel Arastrrma Sürecinde Nicel Veri Analizi. 2. Baskı. Ankara: Pegem Akademi.

Çakmakçı, E., Sanioğlu, A., Patlar, S., Çakmakçı, O., Çınar, V. (2005). Menstruasyonun Anaerobik Güce Etkisi. Spormetre Beden Eğitimi ve Spor Bilimleri Dergisi. 3(4): 145-149.

Demir, B., Algül, L.Y., Güven, E.S.G. (2006). Sağlık Çalışanlarında Premenstrüel Sendrom İnsidans1 ve Etkileyen Faktörlerin Araştırılması. Türk Jinekoloji ve Obstetrik Derneği Dergisi. 3(4): 262-270.

Dickerson, L.M., Mazyck, P.J., Hunter, M.H. (2003). Premenstrual Syndrome. American Family Physician. 67(8): 1743-1752.

Erbil, N., Bölükbaş, N., Tolan, S., Uysal, F. (2011). Evli Kadınlarda Premenstrual Sendrom Görülme Durumu ve Etkileyen Faktörlerin Belirlenmesi. Uluslararası Insan Bilimleri Dergisi. 8(1): 827-838.

Gençdoğan, B. (2006). Premenstruel Sendrom İçin Yeni Bir Ölçek. Türkiye’de Psikiyatri, 8(2), 81 87. 
Akkus, M. Tamer, K., \& Cetin, E. (2017).Investigating the effect of premenstrual syndrome in high school students doing regular sports. Journal of Human Sciences, 14(4), 3379-3388. doi:10.14687/jhs.v14i4.4517

Hekim, M. (2016). Kadın Sporcularda Görülen Menstrüel Düzensizlikler. Uluslararası Hakemli Kadın Hastahkelar ve Anne Cocuk Sağluğ Dergisi. 7: 42-57.

Janssen, I., Katzmarzyk, P. T., Boyce, W. F., Vereecken, C., Mulvihill, C., Roberts, C., ... \& Pickett, W. (2005). Comparison of Overweight and Obesity Prevalence in School-Aged Youth From 34 Countries and Their Relationships With Physical Activity And Dietary Patterns. Obesity Reviews. 6: 123-132.

Karacan, S., Çolakoğlu, F. F. (2003). Türk Elit Bireysel Bayan Sporcuların Menstruel Durumlarının Değerlendirilmesi. TS A Dergisi. 5(2): 194-209.

Karp, J., Smith, C. (2012). Does a Woman's Menstrual Cycle Affect Her Running Performance? http://www.humankinetics.com/news-and-excerpts/news-and-excerpts/does-a-womansmenstrual-cycle-affect-her-running-performance- 27.01.2017.

Kebapçlar, A.G., Taner, C.E., Başoğul, Ö., Okan, G. (2012). İzmir Ege Doğumevi ve Kadın Hastalıkları Eğitim ve Araştırma Hastanesi Hastalarındaki Premenstrüel Sendrom Prevelansı ve Etkileyen Faktörler. Furat Üniversitesi Sağhlk Bilimleri T⿰力 Dergisi. 26(3): 111-114.

Keskin, Ö. (2014). Effects of Physical Education and Participation the Sportss on Social Development in Children. Journal of International Multidisciplinary Academic Researches. 1(1): 1-6.

Lustyk, M. K. B., Widman, L., Paschane, A., Ecker, E. (2004). Stress, Quality of Life and Physical Activity in Women with Varying Degrees of Premenstrual Symptomatology. Women \& Health. 39(3): 35-44.

Ön, S. (2012). Adolesan Voleybolcularda Menstruasyonun Anaerobik Güce ve Aktif Šçrama Performansina Etkisi. Yüksek Lisans Tezi. Ankara Üniversitesi Sağllk Bilimleri Enstitüsü. Ankara.

Öztürk, S., Tanrrverdi, D. (2010). Premenstrual Sendrom ve Başetme. Anadolu Hemşirelik ve Sağhlk Bilimleri Dergisi. 13(3): 57-61.

Roupas, N. D., Georgopoulos, N. A. (2011). Menstrual Function in Sportss. Hormones. 10(2): 104116.

Serena, S., Khaled, M.K.I., O’Brien, S. (2001). Premenstrual Syndrome. Current Obstetrics Gynaecology. 11: 251-255.

Sokullu, G., Aksu, H. (2015). Premenstrual Sendrom Yakınması Olan Kadınların Yaşam Biçimlerinin İncelenmesi. Sağllk ve Toplum. 25(2): 54-62.

Süer, N. (2008). Premenstrual Sendrom. Göztepe Thp Dergisi. 23(3): 76-80.

Şahin, A. (2015). Engellilerde Sosyal Gelişim Yetersizlikleri: Sosyalleşme Sürecinde Sporun Faydaları. Uluslararası Multidisipliner Akademik Arasttrmalar Dergisi. 2(3): 20-28.

Yonkers, K.A., O’Brien, P.M.S., Eriksson, E. (2008). Premenstrual Syndrome. Lancet. 371(9619): 1200-1210. 